\title{
molecules
}

ISSN 1420-3049

www.mdpi.com/journal/molecules

Article

\section{(-)-Kunstleramide, a New Antioxidant and Cytotoxic Dienamide from the Bark of Beilschmiedia kunstleri Gamble}

\author{
Abbas Mollataghi ${ }^{1}$, A. Hamid A. Hadi ${ }^{1, *}$ and Shiau-Chuen Cheah ${ }^{2,3}$
}

1 Department of Chemistry, Faculty of Science, University of Malaya, Kuala Lumpur 50603,

Malaysia; E-Mail: abbas@siswa.um.edu.my

2 Centre for Natural Products Research and Drug Discovery (CENAR), Department of Pharmacology, Faculty of Medicine, University of Malaya, Kuala Lumpur 50603, Malaysia;

E-Mail: cheahsc@um.edu.my

3 School of Medicine, Faculty of Medical Sciences, UCSI University, Kuala Lumpur 56000, Malaysia

* Author to whom correspondence should be addressed; E-Mail: ahamid@um.edu.my;

Tel.: +603-7967-4010; Fax: +603-7967-4193.

Received: 13 February 2012; in revised form: 21 March 2012 / Accepted: 22 March 2012 /

Published: 5 April 2012

Abstract: A new dienamide, (2E,4E)-7-(3',4'-dimethoxyphenyl)- $N$-ethyl-6-( $R$ )-hydroxyhepta2,4-dienamide, named (-)-kunstleramide (1), were isolated from the bark of Beilschmiedia kunstleri Gamble together with one neolignan: (+)-kunstlerone (2) and seven known alkaloids: (+)-nornuciferine (3), (-)-isocaryachine (4), (+)-cassythicine (5), (+)-laurotetanine (6), (+)-boldine (7), noratherosperminine (8), (+)- $N$-demethylphyllocaryptine (9). Their structures were established from spectroscopic techniques, most notably 1D- and 2D-NMR, UV, IR, OR, circular dichroism (CD) spectra and LCMS-IT-TOF. (-)-Kunstleramide (1) exhibited very poor dose-dependent inhibition of DPPH activity, with an $\mathrm{IC}_{50}$ value of $179.5 \pm 4.4 \mu \mathrm{g} / \mathrm{mL}$, but showed a moderate cytotoxic effect on MTT assays of A375, A549, HT-29, PC-3 and WRL-68 with $\mathrm{EC}_{50}$ values of 64.65, 44.74, 55.94, 73.87 and $70.95 \mu \mathrm{g} / \mathrm{mL}$, respectively.

Keywords: Beilschmiedia kunstleri; lauraceae; alkaloid; dienamide; antioxidant; cytotoxicity 


\section{Introduction}

In continuation of our research on the medicinal plants from Malaysian flora [1-3], we have performed a phytochemical investigation on the bark of a Malaysian Lauraceae, Beilschmiedia kunstleri Gamble, which has led to the isolation of a new dienamide, (2E,4E)-7-(3',4'-dimethoxyphenyl)- $N$ ethyl-6-(R)-hydroxyhepta-2,4-dienamide, named (-)-kunstleramide (1). In addition, seven known alkaloids: (+)-nornuciferine (3) [4], (-)-isocaryachine (4) [5], (+)-cassythicine (5) [6], (+)-laurotetanine (6) [7], (+)-boldine (7) [8], noratherosperminine (8) [9], (+)- $N$-demethylphyllocaryptine (9) [8] and one neolignan, (+)-kunstlerone (2) [10], were also isolated (Figure 1). This paper describes the structural elucidation, the DPPH activity with an $\mathrm{IC}_{50}$ value and cytotoxic effect of (-)-kunstleramide (1).

Figure 1. Chemical structures of compounds 1-9.<smiles>CCNC(=O)/C=C/C=C/[C@@H](C)Cc1ccc(O)c(O)c1</smiles>

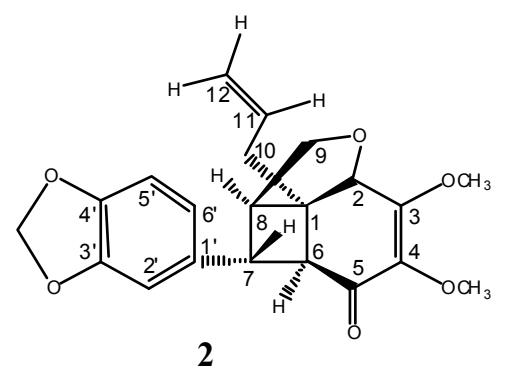<smiles>COc1cc2c3c(c1O)-c1ccccc1CC3(C)NCC2</smiles>

3<smiles>COc1cc2c(cc1O)-c1c(O)c(O)cc3c1[C@](C)(C2)NCC3</smiles>

6

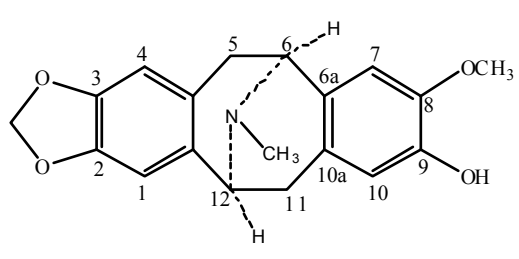

4<smiles>COc1cc2c(cc1O)C[C@@]1(C)c3c(cc(O)c(O)c3-2)CCN1C</smiles>

7<smiles>COc1cc2c(cc1O)C[C@@]1(C)c3cc(O)ccc3-c3c4c(cc(c31)CCN2C)COC4</smiles><smiles>CNCC=Cc1cc(O)c(O)c2c1ccc1ccccc12</smiles><smiles></smiles> 
There are no previous reports on dienamides isolated from the Lauraceae species, although they are reported to occur in another plant species such as Zanthoxylum ailanthoides Sieb. and Zucc. (Rutaceae), Piper maingayi (Piperaceae) and Fagara zanthoxyloides Lam. (Rutaceae) [11-14]. Recently, we have reported one new antioxidant neolignan from the leaves of Beilschmiedia species [10].

\section{Results and Discussion}

(-)-Kunstleramide (1) was isolated as a yellowish amorphous solid. The LC-MS-IT-TOF revealed a pseudomolecular ion peak at $\mathrm{m} / z$ 328.1531 $\left[\mathrm{M}+\mathrm{Na}^{+}\right]$, thus suggesting a molecular formula of $\mathrm{C}_{17} \mathrm{H}_{23} \mathrm{NO}_{4}$ (calc. 305.1525). The IR spectrum showed the presence of the bands at 1,612 and 1,659 $\mathrm{cm}^{-1}$, due to $\mathrm{C}=\mathrm{C}$ and $\mathrm{C}=\mathrm{O}$, and $3,351 \mathrm{~cm}^{-1}$ due to $\mathrm{NH}$ and $\mathrm{OH}$ stretching vibrations, respectively $[15,16]$. The ${ }^{1} \mathrm{H}-\mathrm{NMR}$ spectrum (Table 1) established the presence of three aromatic protons at $\delta 6.66(1 \mathrm{H}, d$, $\left.J=1.8 \mathrm{~Hz}, \mathrm{H}-2^{\prime}\right), 6.67\left(1 \mathrm{H}, d d, J=8.2,1.8 \mathrm{~Hz}, \mathrm{H}-6^{\prime}\right)$ and $6.76\left(1 \mathrm{H}, d, J=8.2 \mathrm{~Hz}, \mathrm{H}-5^{\prime}\right)$ and two methoxyl groups at $\delta 3.79\left(3 \mathrm{H}, s, 4^{\prime}-\mathrm{OCH}_{3}\right)$ and $3.81\left(3 \mathrm{H}, s, 3^{\prime}-\mathrm{OCH}_{3}\right)$.

Table 1. ${ }^{1} \mathrm{H}-\mathrm{NMR}(400 \mathrm{MHz})$ and ${ }^{13} \mathrm{C}-\mathrm{NMR}(100 \mathrm{MHz})$ spectral data of (-)-kunstleramide (1) in $\mathrm{CDCl}_{3}$.

\begin{tabular}{|c|c|c|}
\hline Position & ${ }^{1} \mathbf{H}\left(\delta_{\mathrm{H}}, \mathbf{H z}\right)$ & ${ }^{13} \mathrm{C}$ \\
\hline $\mathrm{C}=\mathrm{O}$ & - & 165.8 \\
\hline $\mathrm{C}-2$ & $5.74, d(15.1)$ & 124.2 \\
\hline $\mathrm{C}-3$ & $7.15, d d(15.1,8.9)$ & 140.0 \\
\hline $\mathrm{C}-4$ & $6.26, d d(15.1,11.2)$ & 127.7 \\
\hline C-5 & $6.06, d d(15.1,5.1)$ & 142.3 \\
\hline C-6 & $4.37, \mathrm{~m}$ & 72.6 \\
\hline $\mathrm{C}-7$ & $\begin{array}{l}2.66, d d\left(J_{\beta}=13.1,5.1\right), \\
2.80, d d\left(J_{\alpha}=13.1,5.1\right)\end{array}$ & 43.4 \\
\hline C-8 & $3.30, q(7.4)$ & 34.6 \\
\hline $\mathrm{C}-9$ & $1.10, t(7.4)$ & 14.9 \\
\hline $\mathrm{C}-1^{\prime}$ & - & 129.5 \\
\hline $\mathrm{C}-2^{\prime}$ & $6.66, d(1.8)$ & 112.6 \\
\hline C-3' & - & 147.9 \\
\hline 3 '-OMe & $3.81, s$ & 55.9 \\
\hline C-4' & - & 149.9 \\
\hline 4'-OMe & $3.79, \mathrm{~s}$ & 55.9 \\
\hline C-5' & $6.76, d(8.2)$ & 111.3 \\
\hline C-6' & $6.67, d d(8.2,1.8)$ & 121.6 \\
\hline $\mathrm{N}-\mathrm{H}$ & $5.43, b r s$ & - \\
\hline $\mathrm{O}-\mathrm{H}$ & $1.67, b r s$ & - \\
\hline
\end{tabular}

Signals representing an $N$-ethyl attached to $\mathrm{C}=\mathrm{O}$ appeared as a quartet at $\delta 3.30$ (methylene) and a triplet at $\delta 1.10$ for the methyl group. The H-6 methine appeared as a multiplet at $\delta 4.37$ and the H-7 methylene showed two doublet of doublets at $\delta 2.66$ and $2.80(J=13.1$ and $5.1 \mathrm{~Hz})$, respectively. The olefinic proton was observed at $\delta 5.74(J=15.1 \mathrm{~Hz})$ as a doublet for H-2. A doublet of doublets at $\delta 7.15$ $(J=15.1$ and $8.9 \mathrm{~Hz})$ was assigned to H-3. Another two olefenic protons, H-4 and H-5 appeared at $\delta 6.26(J=15.1$ and $11.2 \mathrm{~Hz})$ as doublet of doublets and at $\delta 6.06(J=15.1$ and $5.1 \mathrm{~Hz})$ as a doublet of doublets, respectively. Therefore, the structure of compound 1 was unambiguously determined as $(2 E, 4 E)$, 
which was also confirmed by H-H COSY, H-H NOESY, and DEPT spectra [16]. ${ }^{13} \mathrm{C}-\mathrm{NMR}$ and DEPT spectra (Table 1) showed three methyls, two methylenes, eight methines, three quaternary carbons and one carbonyl. The $\mathrm{sp}^{2}$ carbon of $\mathrm{C}-2$ bearing an ethyl amide group gave a signal at $\delta 124.2$, while the carbonyl group was observed at $\delta 165.8$ [16]. The correlations of $\mathrm{H}-2$ and $\mathrm{H}-8$ with $\mathrm{C}-1$, and $\mathrm{H}-\mathrm{N}$ with $\mathrm{C}-8$ in the HMBC spectrum further confirmed the position of ethyl amide fragment at $\mathrm{C}-1$. In addition, the cross-peaks in the COSY spectrum were observed between $\mathrm{H}-2 / \mathrm{H}-3, \mathrm{H}-3 / \mathrm{H}-4, \mathrm{H}-4 / \mathrm{H}-5, \mathrm{H}-5 / \mathrm{H}-6$, H-6/H-7 and H-5'/H-6'. The chemical shifts of proton and carbon were shown in Table 1 and the $\mathrm{H}-\mathrm{H}$ correlations and H-C connectivity are shown in Figure 2.

Figure 2. Selected 2D-NMR (HMBC and COSY) correlations of (-)-kunstleramide(1).

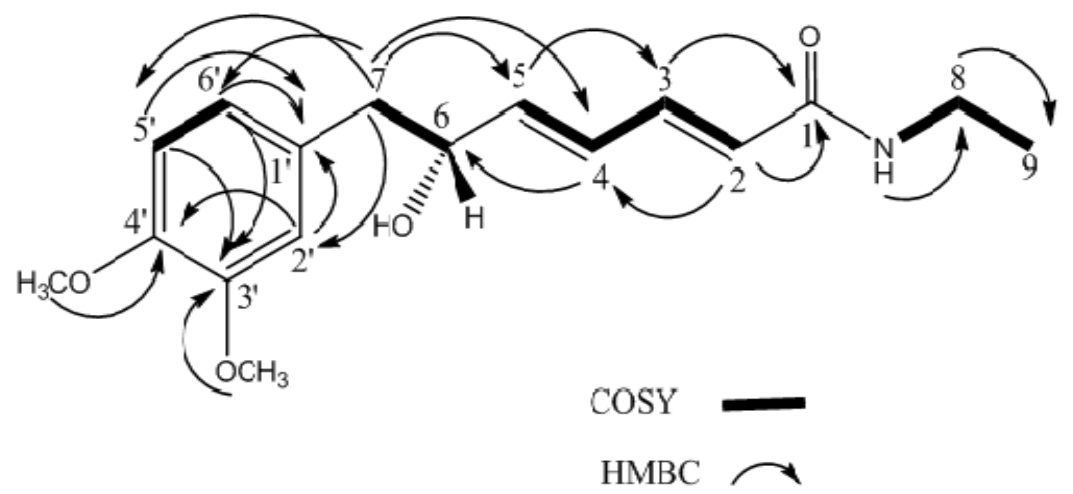

The configuration of proton at C-6 was confirmed based on the analysis of NOESY spectrum. NOESY correlations were observed between $\mathrm{H}-9(\delta 1.10) / \mathrm{H}-8(\delta 3.30), \mathrm{H}-3(\delta 7.15) / \mathrm{H}-5(\delta 6.06)$,

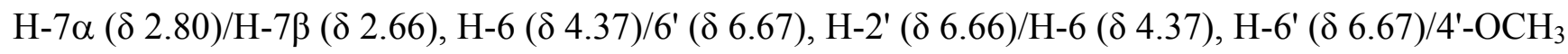
$(\delta 3.79)$ and $\mathrm{H}^{-5}{ }^{\prime}(\delta 6.76) / 4^{\prime}-\mathrm{OCH}_{3}(\delta 3.79)$ respectively (Figure 3$)$.

Figure 3. Selected NOESY correlation of (-)-kunstleramide (1).

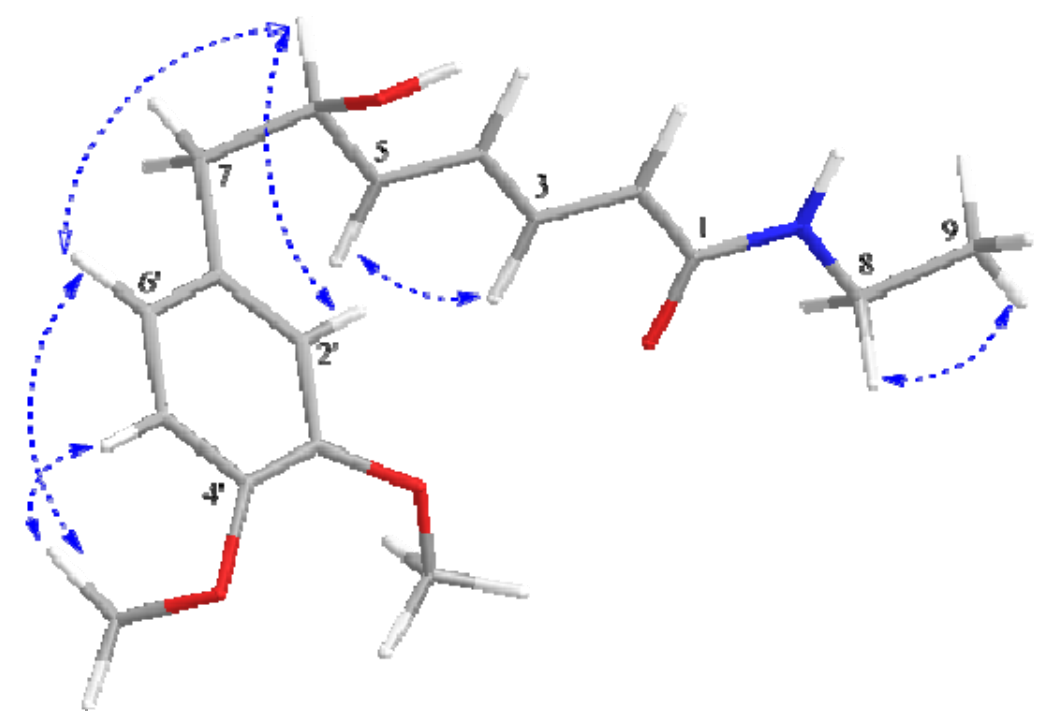

Consequently, the relative configuration of C-6 proton was $R$ and the optical rotation is $-15.48^{\circ}$. Since compound (1) is a chiral, there is a Cotton effect at the position of the chromophore band. The CD (circular dichroism) showed two Cotton effect curves with opposite sign around $\lambda_{\max } 262 \mathrm{~nm}$ 
separated by a Davydov splitting. Therefore, the chirality of compound $\mathbf{1}$ is due to the chiralities between the electric dipole transition moments of both chromophore (the benzene and the unsaturated amide) $[17,18]$. Based on the above spectroscopic data, it was confirmed that compound $\mathbf{1}$ was $(2 E, 4 E)-7-(3 ', 4$ '-dimethoxyphenyl)- $N$-ethyl-6-( $R$-hydroxyhepta-2,4-dienamide, and it was named $(-)$-kunstleramide.

\subsection{Antioxidant Activity}

The antioxidant activity of (-)-kunstleramide (1) was tested using a DPPH assay. Antioxidants are substances that may protect cells from the damage caused by unstable molecules known as free radicals [19]. Free radicals from oxidative stress are involved in many disorders like neurodegenerative diseases and cancer [20]. The new dienamide, (-)-kunstleramide (1) exhibited very poor DPPH activity, with an $\mathrm{IC}_{50}$ value of $179.5 \pm 4.4 \mu \mathrm{g} / \mathrm{mL}$ compared to ascorbic acid (Figure 4). Factors such as growth conditions, stability of the specific antioxidant components, including variations in the process of extraction can influence the variations in the antioxidant activity [21].

Figure 4. $\mathrm{IC}_{50}$ values of (-)-kunstleramide (1). AA: ascorbic acid as control. Results are means $\pm \mathrm{SD}$ of two replicates.

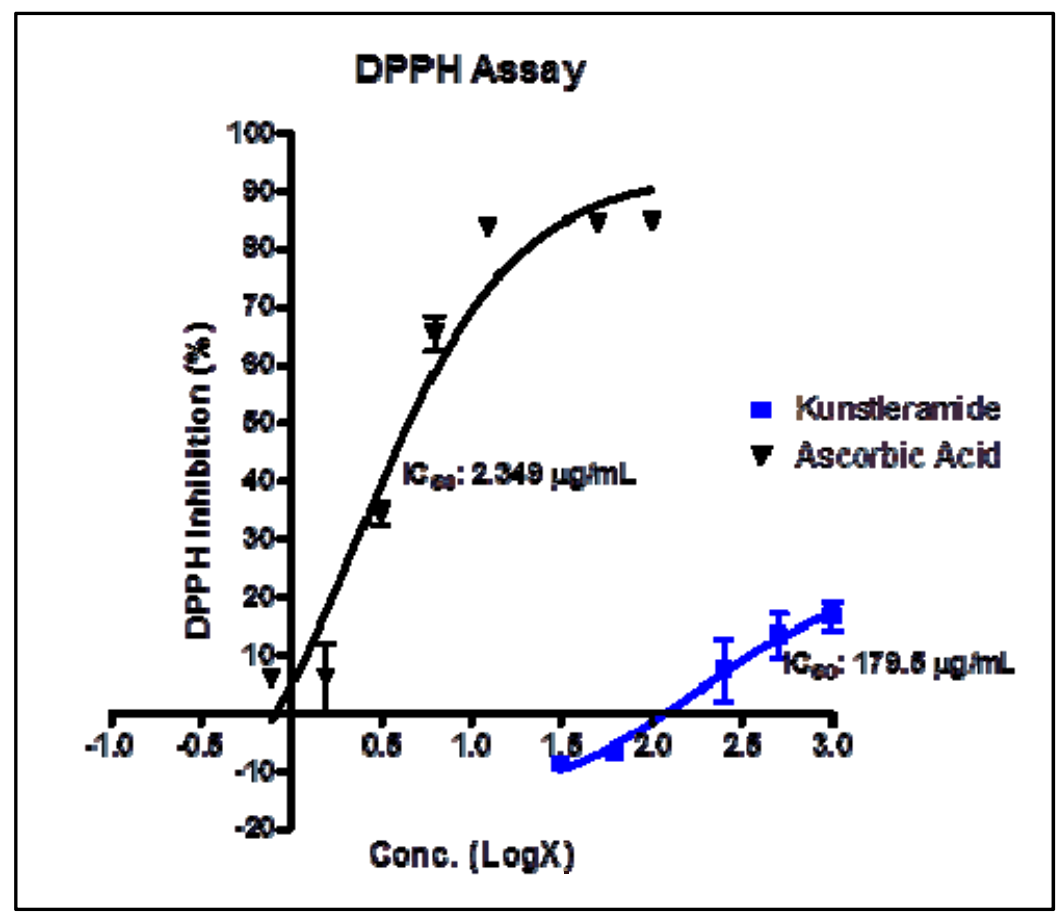

\subsection{Cytotoxic Activity}

To evaluate the cytotoxic activity, the new compound (-)-kunstleramide (1) was tested with a series of different doses on A549, PC-3, A375, HT-29 and WRL-68, respectively (Figure 5). After 24 h, cell viability was determined by the MTT assay. Test agents induced cell cytotoxicity in a concentration dependent manner. These dose titration curves allowed determining $\mathrm{EC}_{50}$ for the test agents towards different cell lines (Table 2). 
Figure 5. Dose-response curves (using GraphPad Prism) tested with (-)-kunstleramide (1) and doxorubicin (positive control) in the MTT assays towards (A) A375, (B) A549, (C) HT-29, (D) PC-3 and (E) WRL-68.

A

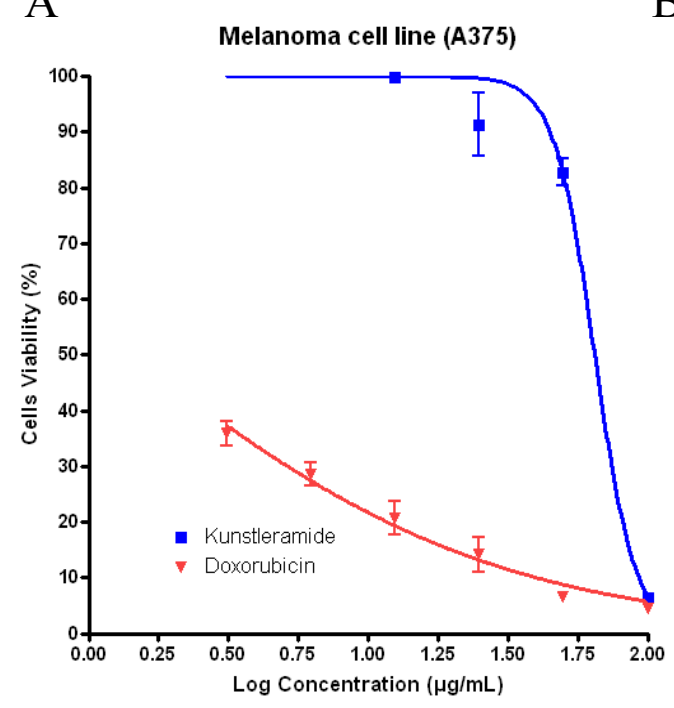

$\mathrm{C}$

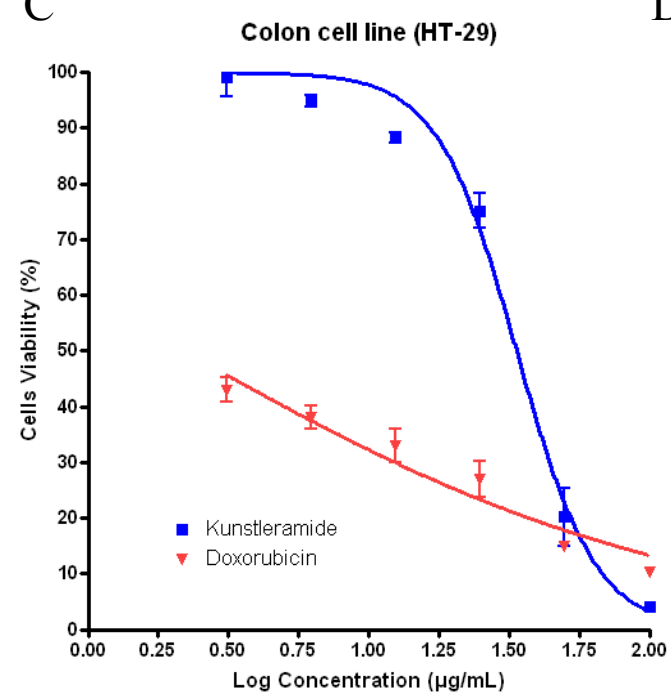

B

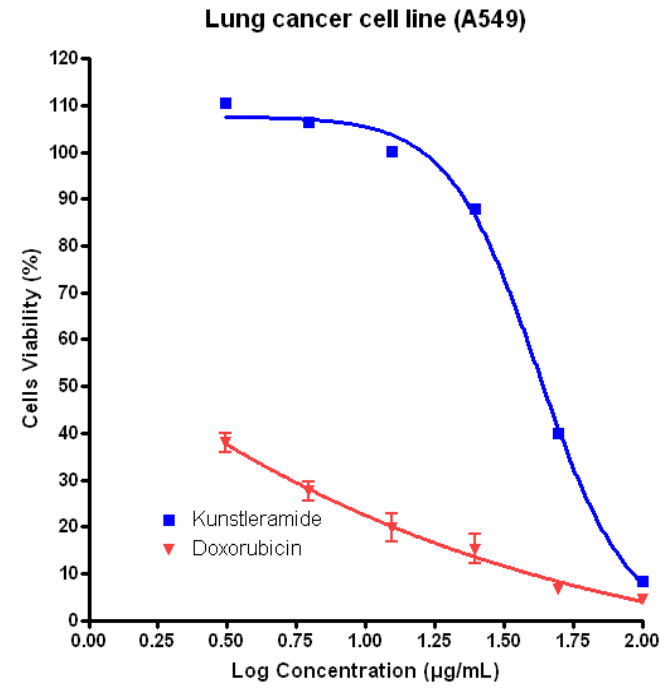

$\mathrm{D}$

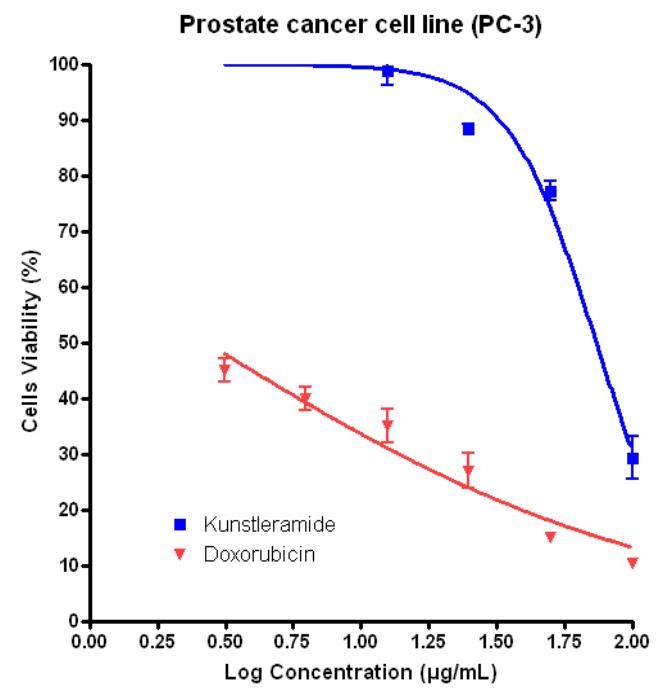

$\mathrm{E}$

Normal liver cell line (WRL-68)

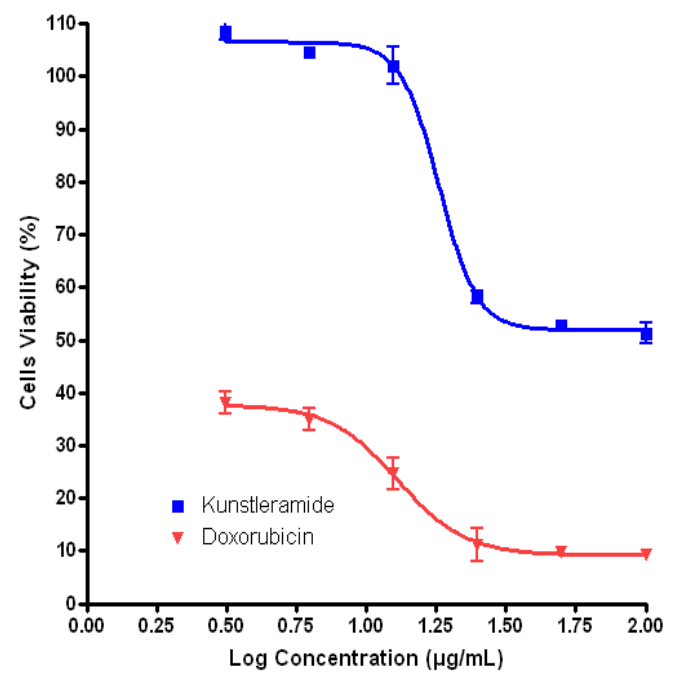


Table 2. Effect of compounds (-)-kunstleramide (1) and doxorubicin (positive control) on different cells type expressed as $\mathrm{EC}_{50}$ values in $24 \mathrm{~h}$ MTT assay. [ $\left.\mathrm{EC}_{50} \pm \mathrm{S} . \mathrm{D}(\mu \mathrm{g} / \mathrm{mL})\right]$.

\begin{tabular}{ccc}
\hline Cell line & New Dienamide & Doxorubicin \\
\hline A375 & 64.65 & 1.364 \\
A549 & 44.74 & 1.550 \\
HT-29 & 55.94 & 1.957 \\
PC-3 & 73.87 & 2.125 \\
WRL-68 & 70.95 & 1.731 \\
\hline
\end{tabular}

From Figure 5, (-)-kunstleramide (1) showed cytotoxic effect on several of the cancer cell lines with different $\mathrm{EC}_{50}$ values as compared to the standard, Doxorubicin (Figure 6). This compound showed moderately cytotoxic effect. (-)-Kunstleramide (1) demonstrated dose-depended cytotoxic effects $\mathrm{EC}_{50}$ values of $64.65,44.74,55.94,73.87$ and $70.95 \mu \mathrm{g} / \mathrm{mL}$; in A375, A549, HT-29, PC-3 and WRL-68, respectively. These results indicate that cell lines differ in their sensitivity to the same test agent, which may be determined by multiple cell type-specific signalling cascades and transcription factor activities.

To our knowledge, the cytotoxic potentials of (-)-kunstleramide (1) have not been examined and the underlying molecular mechanisms remain to be discovered.

Figure 6. Dose-response curves (using GraphPad Prism) tested with doxorubicin (positive control) in the MTT assays towards A375, A549, HT-29, PC-3 and WRL-68.

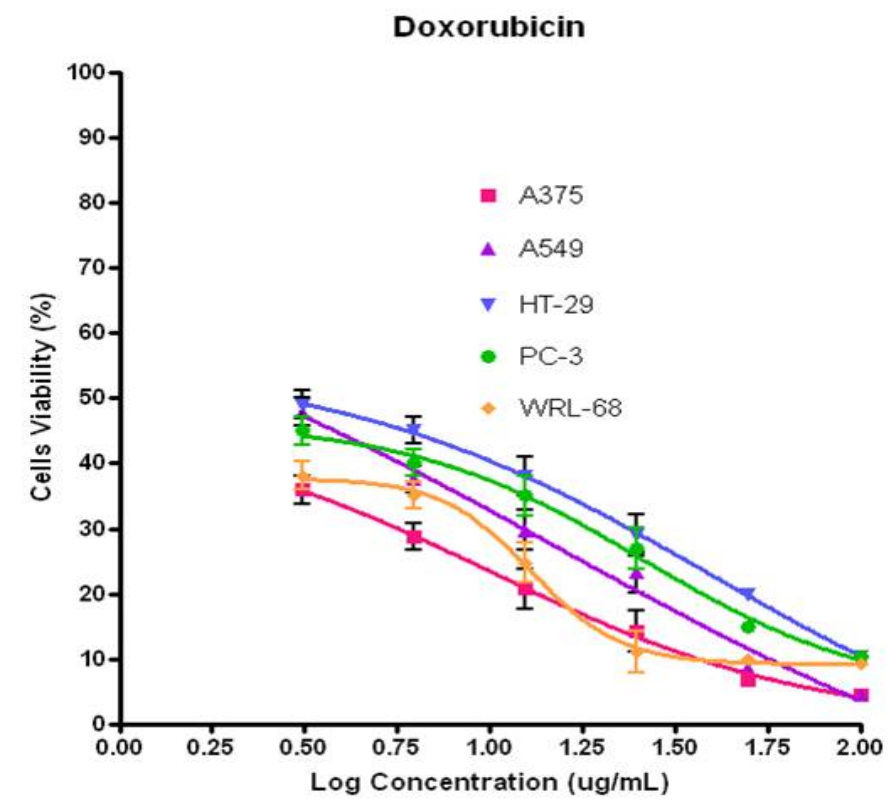

\section{Experimental}

\subsection{General}

The Fourier Transform Infrared (FT-IR) spectra were obtained with $\mathrm{CHCl}_{3}$ ( $\mathrm{NaCl}$ window technique) on a Perkin Elmer 2000 instrument. The ultraviolet spectra (UV) were obtained in $\mathrm{MeOH}$ on a Shimadzu UV-310 ultraviolet-visible spectrophotometer. The OR (optical rotation) was recorded 
on a JASCO (Japan) P1020 Polarimeter equipped with a tungsten lamp (MeOH as solvent) and CD (circular dichroism) data was recorded on a JASCO (Japan) J-815 spectrometer equipped with a tungsten lamp (MeOH as solvent). Mass spectra were obtained using LCMS-IT-TOF, Shimadzu spectrometer Series Mass Selective Detector, Agilent Technologies 6530 Accurate-Mass Q-TOF LC/MS, with ZORBAX Eclipse XDB-C18 Rapid Resolution HT $4.6 \mathrm{~mm}$ i.d. $\times 50 \mathrm{~mm} \times 1.8 \mu \mathrm{m}$ column. Solvent used was methanol $\left(\mathrm{CH}_{3} \mathrm{OH}\right)$. The Auto mass Multi Thermofinnigan was used for HR ESI analysis and EIMS spectra were obtained on Shimadzu LCMS-IT-TOF Mass Spectrometer, QP2000A spectrometer $70 \mathrm{eV}$. NMR spectra were recorded in deuterated chloroform $\left(\mathrm{CDCl}_{3}\right)$ and deuterated methanol $\mathrm{CD}_{3} \mathrm{OD}$ ) on JEOL LA400 FT-NMR and JEOL ECA 400 FT-NMR as a JEOL JNM-FX400 (400 MHz for ${ }^{1} \mathrm{H}$ and $100 \mathrm{MHz}$ for ${ }^{13} \mathrm{C}$; unless stated otherwise) and signal of spectra calibrated using TMS. Chemical shifts were reported in ppm on $\delta$ scale, and the coupling constants were measured in Hertz (Hz). Silica gel 60, 70-230 mesh ASTM (Merck 7734) was used for various column chromatography methods such as CLC and FLC.TLC aluminum sheets and PTLC $(20 \times 20 \mathrm{~cm}$ Silica gel $60 \mathrm{~F}_{254}$ ) were used in the thin layer chromatography analysis. The TLC and PTLC spots were visualized under UV light (254 and $366 \mathrm{~nm}$ ) followed by spraying with Dragendorff's reagent for detection of alkaloids. Dragendorff's reagent and Mayer's reagent were used for alkaloid screening. All solvents used were of AR grade except those used for bulk extraction.

\subsection{Plant Materials}

The bark of Beilschmiedia kunstleri Gamble (Lauraceae) was collected at Hutan Simpan Sungai Tekam, Jerantut, Pahang, Malaysia by the phytochemical group of the Department of Chemistry, University of Malaya. The voucher specimen (KL5627) of this plant has been deposited at the Herbarium of the Department of Chemistry, University of Malaya, Kuala Lumpur, Malaysia.

\subsection{Extraction and Isolation of Chemical Constituents}

Dried, ground stem bark of Beilschmiedia kunstleri Gamble (1.50 kg) was first defatted with hexane $(5.0 \mathrm{~L})$ for $72 \mathrm{~h}$ and then the hexane extract was filtered. The residual bark material was air-dried and moistened with $15 \% \mathrm{NH}_{4} \mathrm{OH}$. It was then extracted with $\mathrm{CH}_{2} \mathrm{Cl}_{2}(10.0 \mathrm{~L})$ for 5 days. After filtration, the supernatant was concentrated using rotary evaporator under reduced pressure to a volume of $500 \mathrm{~mL}$, followed by acidic extraction with $5 \% \mathrm{HCl}$ until a negative Mayer's test result was obtained. The hydrochloric acid portion was washed with $\mathrm{CH}_{2} \mathrm{Cl}_{2}$, basified with $\mathrm{NH}_{4} \mathrm{OH}$ to $\mathrm{pH} 11$ and re-extracted with $\mathrm{CH}_{2} \mathrm{Cl}_{2}$. The $\mathrm{CH}_{2} \mathrm{Cl}_{2}$ extract was washed with distilled $\mathrm{H}_{2} \mathrm{O}$, dried over anhydrous sodium sulphate, filtered and evaporated to give crude alkaloid $(2.90 \mathrm{~g})$. The extraction of alkaloids was repeated by using $\mathrm{MeOH}$ as the solvent and crude alkaloid (10.00 g) was obtained. The crude alkaloid $(2.90 \mathrm{~g})$ was subjected to exhaustive column chromatography over silica gel using $\mathrm{CH}_{2} \mathrm{Cl}_{2}$ and gradually increasing the polarity with methanol to give 12 fractions. Fraction 9 gave a new compound $\mathbf{1}$ (38.05 mg, 1.30\%, PTLC Merck KGaA silica gel $60 \mathrm{~F}_{254} ; \mathrm{CH}_{2} \mathrm{Cl}_{2}-\mathrm{MeOH}$; 90:10), fraction 10 gave alkaloid 3 (23.55 mg, 0.80\%, $\left.\mathrm{CH}_{2} \mathrm{Cl}_{2}-\mathrm{MeOH} ; 85: 15\right)$, fraction 7 afforded alkaloid 4 (19.52 mg, 0.67\%, $\mathrm{CH}_{2} \mathrm{Cl}_{2}-\mathrm{MeOH}$; 95:5), fraction 3 gave alkaloid 5 (19.00 mg, 0.65\%, $\left.\mathrm{CH}_{2} \mathrm{Cl}_{2}-\mathrm{MeOH} ; 98: 2\right)$, fraction 1 gave alkaloid $6\left(32.20 \mathrm{mg}, 1.13 \%, \mathrm{CH}_{2} \mathrm{Cl}_{2}-\mathrm{MeOH} ; 98: 2\right)$, fraction 6 afforded alkaloid 8 (24.80 mg, 0.85\%, $\left.\mathrm{CH}_{2} \mathrm{Cl}_{2}-\mathrm{MeOH} ; 96: 4\right)$ and fraction 11 gave alkaloid 9 (27.21 mg, 0.93\%, $\left.\mathrm{CH}_{2} \mathrm{Cl}_{2}-\mathrm{MeOH} ; 80: 20\right)$. 
The crude methanol extract (10.00 g) was subjected to column chromatography over silica gel to yield five fractions. Fraction 3 gave compound 2 (24.45 mg, 0.83\%, $\left.\mathrm{CH}_{2} \mathrm{Cl}_{2}-\mathrm{MeOH} ; 50: 50\right)$, fraction 2 afforded alkaloid 5 (29.50 mg, 1\%, $\left.\mathrm{CH}_{2} \mathrm{Cl}_{2}-\mathrm{MeOH} ; 60: 40\right)$ and fraction 1 gave alkaloid 7 (32.20 mg, $\left.1.13 \%, \mathrm{CH}_{2} \mathrm{Cl}_{2}-\mathrm{MeOH} ; 98: 2\right)$.

(-)-Kunstleramide (1) with $[\alpha]_{D}^{25}:=-15.48^{\circ}\left(C=4.2 \times 10^{-2} \mathrm{M}, \mathrm{MeOH}\right)$, was obtained as a yellowish amorphous solid; UV (MeOH) $\lambda_{\max }: 210$ and $262 \mathrm{~nm}$ [14,15]; $\mathrm{CD}(\mathrm{MeOH}) \lambda_{\max } 260(\Delta \varepsilon+4.0)$, 265 ( $\Delta \varepsilon-3.5$ ); (IR bands (KBr): 3,351.5, 1,659.4, 1,612.2, $351.5 \mathrm{~cm}^{-1}[15,16] ;{ }^{1} \mathrm{H}-\mathrm{NMR}(400 \mathrm{MHz}$, $\mathrm{CDCl}_{3}$ ) and ${ }^{13} \mathrm{C}-\mathrm{NMR}\left(100 \mathrm{MHz}, \mathrm{CDCl}_{3}\right.$ ): (Table 1); LC-MS, MHz: 328.1531 [M+Na] ${ }^{+}$(calc. 328.1525 for $\mathrm{C}_{17} \mathrm{H}_{23} \mathrm{NO}_{4}$ ).

\subsection{Antioxidant Assay}

The DPPH assay was performed according to the method reported by Orhan et al. [22] and Brem et al. [23], with modifications. Briefly, 0.02\% stable DPPH free radical $(50 \mu \mathrm{L})$ in methanol $(100 \mathrm{~mL})$ was added to standard/sample/control $(20 \mu \mathrm{L})$ and methanol $(130 \mu \mathrm{L}$, total assay volume $200 \mu \mathrm{L}$ ) in a 96-well plate. Ascorbic Acid (vitamin C) was used as the standard and blank solvent methanol as the negative control. The absorbance was read at $517 \mathrm{~nm}$ using SUNRISE Microplate Absorbance Reader after $30 \mathrm{~min}$ of incubation at room temperature. The percentage of DPPH free radical inhibition activity was determined according to the formula:

$$
\text { Percentage of DPPH inhibition }(\%)=\frac{[\text { A }(\text { Blank })-A(\text { Standard } / \text { Sample })}{\text { A }(\text { Blank })} \times 100 \%
$$

where $\mathrm{A}$ (Blank) refers to the absorbance of the blank solvent and DPPH at $517 \mathrm{~nm}$ while A(Standard/Sample) refers to the absorbance of Ascorbic Acid and the samples at $517 \mathrm{~nm}$. This formula was also used to determine the concentration of each sample required to quench $50 \%$ of the DPPH free radical activity ( $\mathrm{IC}_{50}$ value) [24].

\subsection{Statistical Analyses}

Each experiment was performed at least twice. Results are expressed as the means value \pm standard deviation (SD). $\log \mathrm{IC}_{50}$ calculations were performed using the built-in algorithms for dose-response curves with variable slope using Graphpad Prism software (version 4.0; GraphPad Software Inc., San Diego, CA, USA). A fixed maximum value of the dose-response curve was set to the maximum obtained value for each drug.

\subsection{Cytotoxic Activity Studies}

\subsubsection{Cell Culture}

All the cells used in this study were obtained from American Type Cell Collection (ATCC) and maintained in a $37{ }^{\circ} \mathrm{C}$ incubator with $5 \% \mathrm{CO}_{2}$ saturation. A375 human melanoma, HT-29 human colon adenocarcinoma cells and WRL-68 normal hepatic cells were maintained in Dulbecco's modified Eagle's medium (DMEM), whereas A549 non-small cell lung cancer cells and PC-3 prostate 
adenocarcinoma cells were maintained in RPMI medium. Both medium were supplemented with $10 \%$ fetus calf serum (FCS), 100 units $/ \mathrm{mL}$ penicillin, and $0.1 \mathrm{mg} / \mathrm{mL}$ streptomycin.

\subsubsection{Cellular Viability}

Different cell types mentioned above were used to evaluate the inhibitory effect of kunstleramide (1) on cell growth using the MTT assay. The MTT assay was modified as described by Cheah et al. and Mosmann [25,26]. Briefly, cells were seeded at a density of $1 \times 10^{5}$ cells $/ \mathrm{mL}$ in a 96-well plate and incubated for $24 \mathrm{~h}$ at $37{ }^{\circ} \mathrm{C}, 5 \% \mathrm{CO}_{2}$. The next day, cells were treated with the compounds respectively and incubated for another $24 \mathrm{~h}$. After $24 \mathrm{~h}$, MTT solution at $2 \mathrm{mg} / \mathrm{mL}$ was added and incubatefor $1 \mathrm{~h}$. Absorbance at $570 \mathrm{~nm}$ was measured and recorded using a Plate Chameleon V microplate reader (Hidex, Turku, Finland). Results were expressed as a percentage of control giving percentage cell viability after $24 \mathrm{~h}$ exposure to test agent. The potency of cell growth inhibition for each test agent was expressed as an $\mathrm{EC}_{50}$ value, defined as the concentration that caused a $50 \%$ loss of cell growth. Viability was defined as the ratio (expressed as a percentage) of absorbance of treated cells to untreated cells [27].

\section{Conclusions}

To the knowledge of the authors, (-)-kunstleramide (1) is the first ethyl dienamide reported in the family of Lauraceae which bears a hydroxyl group at C-6 and two methoxyl groups attached to C-3' and $\mathrm{C}-4$ '. This is the first communication on a dienamide from Beilschmiedia kunstleri. The neolognan (+)-kunstlerone (2) and alkaloids 3-9, belonging to the aporphine, benzylisoquinoline, morphinandienone and pavine type of alkaloids were also isolated from this plant. (-)-Kunstleramide (1) exhibited very poor DPPH, activity with an $\mathrm{IC}_{50}$ value of $179.5 \pm 4.4 \mu \mathrm{g} / \mathrm{mL}$ compared with the DPPH inhibitor ascorbic acid. Kunstleramide (1) showed moderate cytotoxic effect with $\mathrm{EC}_{50}$ values. This study revealed that this plant showed promising cytotoxic activity but poor DPPH activity. Further investigation should be carried out to evaluate the cytotoxicity of compound $\mathbf{1}$ at lower concentrations and its mechanism.

\section{Supplementary Materials}

Supplementary materials can be found at: http://www.mdpi.com/1420-3049/17/4/4197/s1.

\section{Acknowledgements}

The authors acknowledge the financial support provided by University of Malaya Research Grant (UMRG 045/11BIO), Centre of Natural Products and Drugs Development (CENAR), Postgraduate Research Grant of University of Malaya (PS366/2010B) and High Impact Research (HIR) Grant of University of Malaya (F000009-21001). We also acknowledge the support provided by Din Mat Nor and Rafly Syamsir for the plant samples, and Hairin Taha for editorial assistance. 


\section{References and Notes}

1. Kochummen, K.M. Tree Flora of Malaya: A Manual For Foresters; Ng, F.S.P., Ed.; Longman: Selangor, Malaysia, 1989; Volume 4, p. 98.

2. Pudjiastuti, P.; Mukhtar, M.R.; Hadi, A.H.A.; Saidi, N.; Morita, H.; Litaudon, M.; Awang, K. (6,7-Dimethoxy-4-methylisoquinolinyl)-(4'-methoxyphenyl)-methanone, a new benzylisoquinoline alkaloid from Beilschmiedia brevipes. Molecules 2010, 15, 2339-2346.

3. Funasaki, M.; Lordello, A.L.; Viana, A.M.; Santa-Catarina, C.; Floh, E.I.S.; Yoshida, M.; Kato, M.J. Neolignans and sesquiterpenes from leaves and embryogenic cultures of Ocotea catharinensis (Lauraceae). J. Braz. Chem. Soc. 2009, 20, 853-859.

4. Cava, M.P.; Rao, K.V.; Douglas, B.; Weisbach, J.A. Alkaloids of Cassytha Americana. J. Org. Chem. 1968, 33, 2443-2446.

5. Chung-hsiung, C.; Shoei-shen, L.; Chung-fang, L.; Jinn, W.; Jack, L.B. A caryachnine $N$-methosalt from Cryptocarya chinensis and PMR spectral characteristics of some quaternary pavine alkaloids. J. Nat. Prod. 1979, 42, 163-167.

6. Pinheiro, M.L.B.; Xavier, C.M.; Souza, A.D.L.D.; Rabelo, D.D.M.; Batista, C.L.; Batista, R.L.; Costa, E.V.; Campos, F.R.; Barison, A.; Valdez, R.H.; et al. Acanthoic acid and other constituents from the stem of Annona amazonica (Annonaceae). J. Braz. Chem. Soc. 2009, 20, 1095-1102.

7. Babkock, P.A.; Segelman, A.B. Alkaloids of Lindera benzoin (L.) Blume (lauraceae), I: Isolation and identification of laurotetanine. J. Pharm. Sci. 1974, 63, 1495-1496.

8. Cave, A.; Leboeuf, M.; Moskowitz, H.; Ranaivo, A.; Bick, I.; Sinchai, W.; Nieto, M.; Sevenet, T.; Cabalion, P. Alkaloids of Cryptocarya phyllostemon. Aust. J. Chem. 1989, 42, 2243-2263.

9. Ramana, M.M.V.; Prashant, V.P. Tandem acylation-cycloalkylation with cyclohexene-1-acetic acid: A new entry to phenanthrene alkaloids. Nat. Prod. Res.1996, 8, 317-324.

10. Mollataghi, A.; Hamid, A.H.A.; Awang, K.; Jamaludin, M.; Litaudon, M.; Mukhtar, M.R. $(+)-K u n s t l e r o n e$, a new antioxidant neolignan from the leaves of Beilschmiedia kunstleri Gamble. Molecules 2011, 16, 6582-6590.

11. Ahmad, F.; Jamil, S.; Ibrahim, A.Z.; Read, R.W. Alkenylalamides from Piper maingayi Hk. F. Pertanika. J. Sci. Technol.1996, 4, 167-171.

12. Marques, J.V.; Oliveira, A.D.; Raggi, L.; Young, M.C.M.; Kato, M.J. Antifungal activity of natural and synthetic amides from piper species. J. Braz. Chem. Soc. 2010, 21, 1807-1813.

13. Cheng, M.J.; Tsai, I.L. Chen, I.S. Chemical constituents from the root bark of Formosan Zanthoxylum ailanthoides. J. Chin. Chem. Soc. 2003, 50, 1241-1246.

14. Chaaib, F.; Queiroz, E.F.; Ndjoko, K.; Diallo, D.; Hostettmann, K. Antifungal and antioxidant compounds from the root bark of Fagara zanthoxyloides. Planta Med. 2003, 69, 316-320.

15. Zhao, J.; Muhammad, I.; Dunbar, D.C.; Mustafa, J.; Khan, I.A. New alkamides from maca (Lepidium meyenii). J. Agric. Food Chem. 2005, 53, 690-693.

16. Caturla, F.; Najera, C. Lithiated (E)- $N$-isopropyl-5-tosyl-4-pentenamide: Synthetic applications as new $\delta$-acyldienyl anion equivalent. Tetrahedron 1998, 54, 11255-11270.

17. Harada, N.; Nakanishi, K. Exciton chirality method and its application to configurational and conformational studies of natural products. Acc. Chem. Res. 1972, 5, 257-263. 
18. Smith, H.E. Chiroptical properties of the benzene chromophore. A method for the determination of the absolute configurations of benzene compounds by application of the benzene sector and benzene chirality rules. Chem. Rev. 1998, 98, 1709-1740.

19. Blot, W.J.; Li, J.Y.; Taylor, P.R.; Guo, W.; Dawsey, S.; Wang, G.Q.; Yang, C.S.; Zheng, S.F.; Gail, M.; Li, G.Y.; et al. Nutrition intervention trials in Linxian, China: Supplementation with specific vitamin/mineral combinations, cancer incidence, and disease-specific mortality in the general population. J. Natl. Cancer Inst. 1993, 85, 1483-1492.

20. Uddin, N.; Rahman, A.; Uddin, N.A.; Rana, S.; Akter, R.; Chowdhury, M.A. Antioxidant, cytotoxic and antimicrobial properties of Eclipta alba ethanol extract. Int. J. Biol. Med. Res. 2010, 1, 341-346.

21. Price, J.A.; Sanny, C.G.; Sherlin, D. Application of manual assessment of oxygen radical absorbent capacity (ORAC) for use in high throughput assay of "total" antioxidant activity of drugs and natural products. J. Pharmacol. Toxicol. Methods 2006, 54, 56-61.

22. Orhan, M.K.; Naz, Q.; Ejaz, A.; Yilmaz, G.; Kan, Y.; Konuklugil, B.; Sener B.; Choudhary, M.I. Antioxidant and anticholinesterase evaluation of selected Turkish Salvia species. Food Chem. 2007, 103, 1247-1254.

23. Brem, B.; Seger, C.; Pacher, T.; Harti, M.; Hadacek, F.; Hofer, O.; Vajrodaya, S.; Greger, H. Antioxidant dehydrotocopherols as a new chemical character of Stemona species. Phytochemistry 2004, 65, 2719-2729.

24. Enayat, S.; Banerjee, S. Comparative antioxidant activities of extracts from leaves, bark and catkins of Salixa egyptiaca species. Food Chem. 2009, 116, 23-28.

25. Cheah, S.C.; Appleton, D.R.; Lee, S.T.; Lam, M.L.; Hadi, A.H.A.; Mustafa, M.R. Panduratin a inhibits the growth of A549 cells through induction of apoptosis and inhibition of NF-Kappa B translocation. Molecules 2011, 16, 2583-2598.

26. Mosmann, T. Rapid colorimetric assay for the cellular growth and survival: Application to proliferation and cytotoxicity assays. J. Immunol. Methods 1983, 65, 55-63.

27. Braga, P.A.; Dos Santos, D.A.; Da Silva, M.F.; Vieira, P.C.; Fernandes, J.B.; Houghton, P.J.; Fang, R. In vitro cytotoxicity activity on several cancer cell lines of acridone alkaloids and $\mathrm{N}$-phenylethyl-dienamide derivatives from Swinglea glutinosa (B1.) Merr. Nat. Prod. Res. 2007, $21,47-55$.

Sample Availability: Not available.

(C) 2012 by the authors; licensee MDPI, Basel, Switzerland. This article is an open access article distributed under the terms and conditions of the Creative Commons Attribution license (http://creativecommons.org/licenses/by/3.0/). 